\title{
Pendayagunaan Infrastruktur Sanitasi dan Air Bersih dalam Mendukung Kesehatan Masyarakat (Kasus Kabupaten Gresik, Jawa Timur)
}

\author{
Nino Heri Setyoadi \\ Mahasiswa S-2 Prodi Pengelolaan Infrastruktur dan Pembangunan Masyarakat (PIPM) \\ Sekolah Pasca Sarjana Universitas Gadjah Mada - Penerima Beasiswa Unggulan Tahun 2011 \\ e-mail: andik_y@ftsp.uii.ac.id
}

\begin{abstract}
Abstrak
Penyakit diare dan muntaber merupakan salah satu penyakit menular yang masih menjadi masalah utama di Indonesia. Data kementerian kesehatan menunjukkan peningkatan kejadian diare dari tahun ke tahun. Penyediaan dan pendayagunaan infrastruktur sanitasi dan air bersih yang aman menjadi salah satu upaya untuk menekan angka kejadian diare/muntaber (penulisan dikalimat pertama diare dan muntaber). Tulisan ini bertujuan untuk mengidentifikasi dukungan pendayagunaan infrastruktur sanitasi dan air bersih terhadap kesehatan masyarakat. Pendekatan yang digunakan adalah pendekatan kuantitatif dengan level analisis kabupaten Gresik tahun 2011. Data utama yang digunakan bersumber dari data potensi desa tahun 2011 dengan teknik pengolahan data statistik tabulasi silang. Hasil pembahasan menunjukkan pendayagunaan infrastruktur sanitasi dan air bersih di kabupaten Gresik tahun 2011 belum mampu mendukung kesehatan masyarakat terbebas dari penyakit diare dan muntaber. Rekomendasi yang disarankan antara lain peningkatan cakupan air bersih perpipaan, mempromosikan sistem sanitasi perkotaan atau komunal yang aman dan ramah lingkungan, serta melembagakan ketentuan pengelolaan sanitasi dan air bersih aman dan ramah lingkungan dalam peraturan daerah.
\end{abstract}

Kata kunci: Sanitasi, air bersih, jamban, diare dan muntaber

\section{Pendahuluan}

Dalam sebuah laporan resmi yang di rilis oleh Kementerian Kesehatan pada bulan Juni 2011, penyakit diare masih dinilai dan dinyatakan sebagai masalah di Indonesia. Hal ini terlihat dari semakin meningkatnya kejadian diare dari tahun ke tahun. Hasil survei morbiditas yang dilakukan oleh Subdit Diare, Departemen Kesehatan tahun 2000 menunjukkan IR penyakit Diare 301/1000 penduduk, tahun 2003 naik menjadi 374/1000 penduduk, tahun 2006 naik menjadi 423/1000 penduduk dan tahun 2010 menjadi 411/1000 penduduk. Kejadian Luar Biasa (KLB) diare juga masih sering terjadi, dengan CFR yang masih tinggi. Pada tahun 2008 terjadi KLB di 69 Kecamatan dengan jumlah kasus 8133 orang, kematian 239 orang (CFR 2,94\%). Tahun 2009 terjadi KLB di 24 Kecamatan dengan jumlah kasus 5.756 orang, dengan kematian 100 orang (CFR 1,74\%), sedangkan tahun 2010 terjadi KLB diare di 33 kecamatan dengan jumlah penderita 4204 dengan kematian 73 orang atau CFR 1,74 \% (Buletin Jendela, 2011).

Peta sebaran frekuensi KLB diare pada tahun 2009-2010 lebih banyak tersebar di wilayah Sulawesi bagian tengah dan Jawa Timur. Frekuensi KLB diare tahun 2010 di propinsi Sulawesi Tengah sebanyak 27 kali dan Jawa Timur 21 kali. Pada tahun 2009 frekuensi KLB banyak terjadi di 
propinsi Jawa Barat sebesar 33 KLB sedangkan Jawa Timur sebesar 5 KLB. Berdasarkan data tersebut, nampak bahwa propinsi Jawa Timur mengalami lonjakan yang cukup tinggi sebesar 5 kali lipat. Kondisi ini tentu menjadi catatan kesehatan tersendiri bagi wilayah propinsi yang memiliki peran penting dalam perekonomian nasional tersebut (Buletin Jendela, 2011).

Secara lebih kontekstual, di wilayah propinsi Jawa Timur terdapat beberapa kabupaten/kota yang mengalami kejadian diare yang cukup tinggi seperti kabupaten Banyuwangi, Bondowoso dan Gresik. Dari ketiga wilayah ini, kabupaten Gresik menjadi salah satu kasus yang menarik. Sebagai gambaran awal, pada tahun 2006 Jumlah penderita diare pada balita tahun 2006 sebanyak 13.313, meningkat 14,99\% dibanding tahun 2005 sebesar 11.578 balita (Profil Kesehatan Kab. Gresik 2006).

Jika dilihat dari aksesibilitas terhadap infrastruktur air bersih, pada tahun 2006 sebanyak 161.557 keluarga (64,64\%) sudah terlayani air bersih dengan berbagai jenis sumber air bersih. Jika dilihat dari cakupan untuk kepemilikan sanitasi dasar meliputi, keluarga yang memiliki air bersih sehat jumlahnya 160.645 (64,28\%) dari jumlah yang diperiksa (249.909 KK), keluarga yang memiliki akses terhadap jamban sekat 157.334 (62,96\%), keluarga yang mengelola sampah dengan baik jumlahnya 217.723 (87,12\%), keluarga yang mengelola limbahnya dengan aman jumlahnya 158.620 atau sebesar 63,47\% (Profil Kesehatan Kab. Gresik 2006).

Berdasarkan uraian tersebut, nampaknya infrastruktur sanitasi dan air bersih belum sepenuhnya mampu mendukung kesehatan masyarakat kabupaten Gresik, terutama dari kejadian penyakit diare. Setelah berjalan 5 tahun (tahun 2011), berbagai upaya tentunya dilakukan untuk meningkatkan kondisi dan aksesibilitas penduduk terhadap infrastruktur sanitasi dan air bersih. Upaya peningkatan tersebut seharusnya membawa perubahan pada kondisi kesehatan masyarakat. Untuk itu diperlukan sebuah studi mengenai pendayagunaan infrastruktur sanitasi dan air bersih dalam mendukung kesehatan masyarakat di kabupaten Gresik pada tahun 2011.

\section{Metode Penelitian}

Untuk menjawab pertanyaan dan tujuan penelitian diatas, penelitian ini menggunakan pendekatan kuantitatif. Level analisis yang digunakan pada tataran makro tingkat kabupaten Gresik. Penelitian ini sepenuhnya memanfaatkan data sekunder sebagai basis data utama dalam proses analisis. Data sekunder yang digunakan adalah data potensi desa (PODES) tahun 2011 yang dikeluarkan oleh Badan Pusat Statistik. Penggunaan data sekunder ini bisa menghemat waktu, biaya, tenaga dan menyederhanakan prosedur penelitian. Penggunaan data sekunder tentu memiliki kelemahan karena data-data tersebut dikumpulkan orang lain. Pengguna data menjadi sulit untuk mengontrol validitas 
data tersebut. Pengguna seakan-akan dipaksa untuk meyakini bahwa data tersebut telah dikumpulkan secara scientific. Untuk itu sebelum data sekunder digunakan, perlu melakukan pembersihan data (cleaning) agar terhindar dari data yang tumpang tindih (redudance) atau kesalahan-kesalahan yang lain.

Dalam PODES 2011 wilayah kabupaten Gresik terdapat beberapa kesalahan yang harus dibersihkan dahulu. Untuk wilayah kecamatan Tambak, kode propinsi dan kabupaten tertulis dengan propinsi Jawa Tengah dan kabupaten Banyumas. Wilayah kecamatan Dukun juga tertulis propinsi Jawa Tengah Kabupaten Magelang. Kemudian untuk kecamatan Cerme, data jumlah penderita diare/muntaber pada setiap desa berjumlah sama sebanyak 98 orang. Hal ini jelas menunjukkan adanya data yang tumpang-tindih (redudance). Terakhir untuk memudahkan pemetaan, wilayah kecamatan Sangkapura terpisah dengan Gresik daratan. Untuk menghindari kesalahan pengolahan data dan analisis, wilayah kecamatan Tambak, Dukun, Cerme dan Sangkapura tidak disertakan dalam penelitian ini. Dengan demikian hanya 14 kecamatan dan 275 desa yang diteliti dalam penelitian ini.

Penelitian ini menggunakan variabel-variabel yang bersumber dari PODES 2011 dengan beberapa teknik pengolahan sehingga menjadi data baru yang siap di analisis. Variabel dari PODES 2011 yang digunakan adalah sebagai berikut:

1. Jenis sumber air bersih (air kemasan, PAM/PDAM, pompa listrik/tangan, sumur, mata air, sungai/danau/kolam, air hujan, lainnya)

2. Jenis jamban keluarga (jamban sendiri, jamban bersama, jamban umum, bukan jamban)

3. Jumlah penderita diare/muntaber

Khusus untuk data sumber air bersih diolah melalui proses kategorisasi berdasarkan kategori air bersih yang dikeluarkan WHO-UNICEF. Kategori air bersih terdiri dari air bersih terlindungi dan tidak terlindungi sebagaimana diulas dalam kajian pustaka. Air kemasan, PAM/PDAM, pompa listrik/tangan, dan sumur masuk dalam kategori bersih terlindungi sedangkan sumber yang lain tidak terlindungi. Untuk data jamban keluarga tidak dilakukan kategorisasi baru. Kategorisasi jamban mengikuti definisi yang telah dirumuskan oleh BPS sebagaimana diulas dalam kajian pustaka.

Proses analisis data menggunakan teknik statistik tabulasi silang (cross tabulation). Teknik ini digunakan untuk menunjukkan jumlah penderita diare/muntaber pada setiap kategori jamban dan kategori sumber air. Infrastruktur sanitasi berfungsi dengan baik jika jumlah penderita diare/muntaber pada kategori jamban sendiri, bersama, dan umum lebih sedikit dibandingkan dengan kategori bukan jamban. Infrastruktur air bersih berfungsi dengan baik ketika jika jumlah penderita diare/muntaber pada kategori air bersih terlindungi lebih rendah daripada kategori tidak 
terlindungi. Asumsinya, potensi pencemaran air bersih pada kategori bukan jamban dan air bersih tidak terlindungi lebih besar sehingga membawa bibit penyakit diare/muntaber. Pengolahan data memanfaatkan software Ms Access 2007 dan Ms Excel 2007.

Data yang tersaji dalam tabel tabulasi silang akan dianalisis melalui proses deskripsi, tendensi dan interpretasi. Pada proses deskripsi melihat persamaan dan perbedaan karakteristik pendayagunaan sanitasi, air bersih dan dampak kesehatan. Proses tendesi untuk menunjukkan kecenderungankecenderungan dari pendayagunaan sanitasi, air bersih dan dampak kesehatan. Sedangkan proses interpretasi merupakan upaya untuk menafsirkan penyebab terjadinya persamaan dan perbedaan karakteristik serta tendensi yang ada. Interpretasi bisa benar dan bisa salah, namun yang terpenting adalah intrepretasi yang dilakukan bersifat nalar/logis dan sistematis.

Selain teknik tabulasi silang, analisis akan diperkaya dengan visualisasi peta distribusi infrastruktur sanitasi dan air bersih dengan bantuan software ARGIS 10. Dengan peta ini dapat ditunjukkan lokasi mana saja jumlah kejadian diare, jenis sumber air, dan jamban keluarga. Kombinasi peta dapat dibuat seperti peta distribusi kejadian diare pada setiap kategori jamban keluarga dan air bersih. Berdasarkan pola distribusi tersebut bisa dikembangkan berbagai strategi intervensi dan adaptasi yang sesuai.

Adapun prosedur pengolahan data yang digunakan dapat dilihat pada bagan berikut ini.

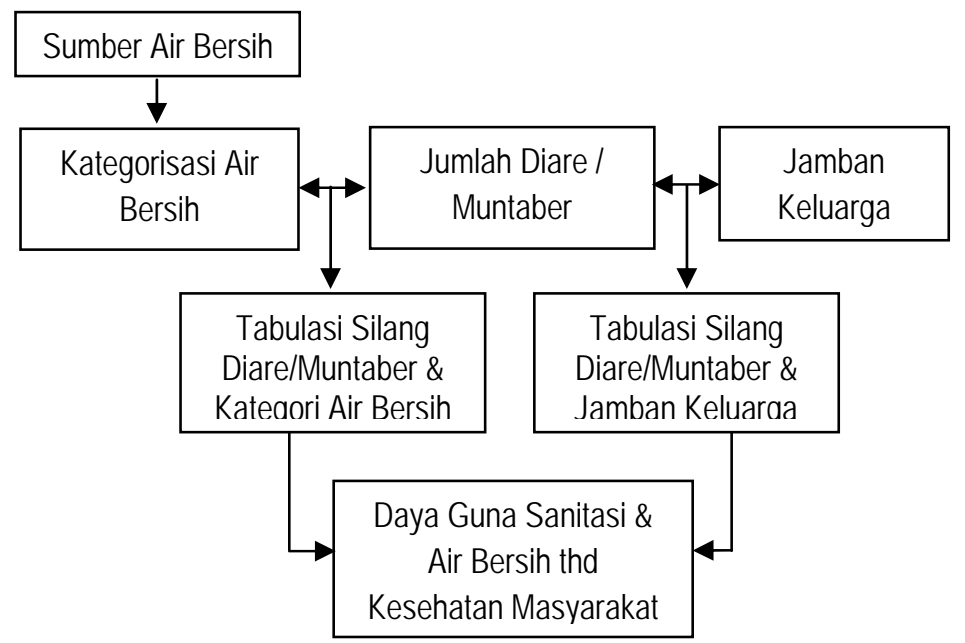

Bagan 2. Prosedur Pengolahan Data PODES 2011

\section{Hasil dan Pembahasan}

Pembangunan sanitasi dan air bersih diyakini dapat meningkatkan kualitas kesehatan masyarakat dan lingkungan. Pembangunan sanitasi dan air bersih bahkan dijadikan sebagai salah satu pintu masuk untuk mereduksi tingkat kemiskinan. Namun fakta dilapangan juga menunjukkan problem sanitasi dan air bersih belum menjadi prioritas dan perhatian utama diberbagai daerah di Indonesia. Sebagian besar kabupaten/kota bahkan enggan mengalokasikan APBD dalam jumlah besar khususnya di bidang sanitasi. Mereka menganggap bidang sanitasi sebagai beban bagi keuangan daerah. 
Infrastruktur sanitasi di Kabupaten Gresik untuk jamban keluarga masih didominasi oleh jamban sendiri (97\%). Kondisi ini memang lazim diberbagai wilayah di pulau Jawa. Persoalannya apakah jamban sendiri yang dibangun setiap rumah sudah memenuhi standar, jarak septik tank dengan sumber air bersih sesuai standar dan sebagainya. Jamban bersama digunakan di 6 desa seperti di desa Mondoluku (kec. Wringinanom), desa Pranti dan Randupadangan (kec. Menganti), Palebon (kec. Duduk Sampeyan), serta desa Sidomukti dan Mojopuro Wetan (kec. Bungah). Desa-desa yang penduduknya belum menggunakan jamban untuk aktifitas buang air besar/kecil (bukan jamban) berada di desa Panjunan, Kemudi dan Bendungan (kec. Duduk Sampeyan). Grafik 1 menunjukkan prosentase penggunaan jamban keluarga di kabupaten Gresik tahun 2011.

Infrastruktur air bersih di kabupaten Gresik memiliki variasi sumber air yang cukup banyak. Penggunaan pompa listrik/tangan dan sumur gali masih dominan (55\%). Jaringan air PDAM baru menjangkau $17 \%$ wilayah desa/kelurahan. Salah satu hal yang menarik adalah penggunaan air kemasan yang jumlahnya cukup signifikan dimana 19 \% desa menggunakannya sebagai sumber air bersih utama. Pemanfaatan air hujan banyak terjadi di kecamatan Duduk Sampeyan (14 desa), sementara untuk sumber lainnya terbanyak di kecamatan Sidayu (13 desa). Grafik 2 menunjukkan proporsi sumber air bersih di kabupaten Gresik tahun 2011.

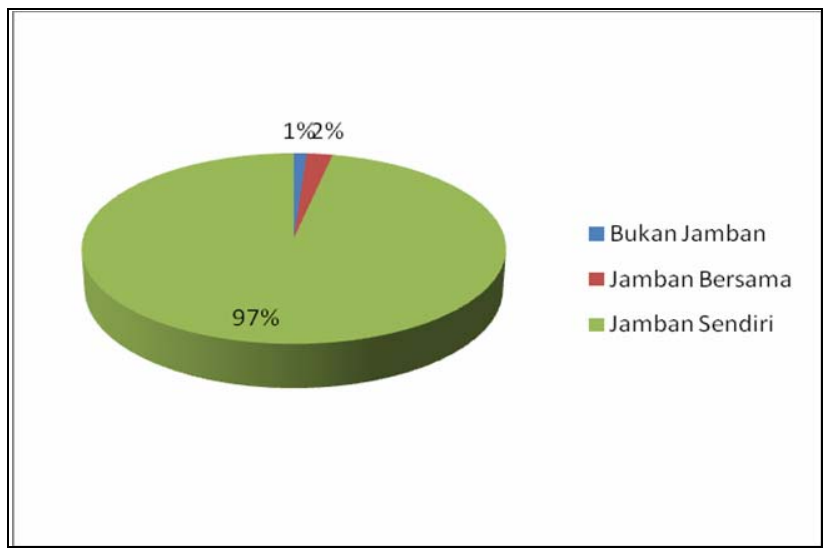

Grafik 1. Prosentase Penggunaan Jamban 2011

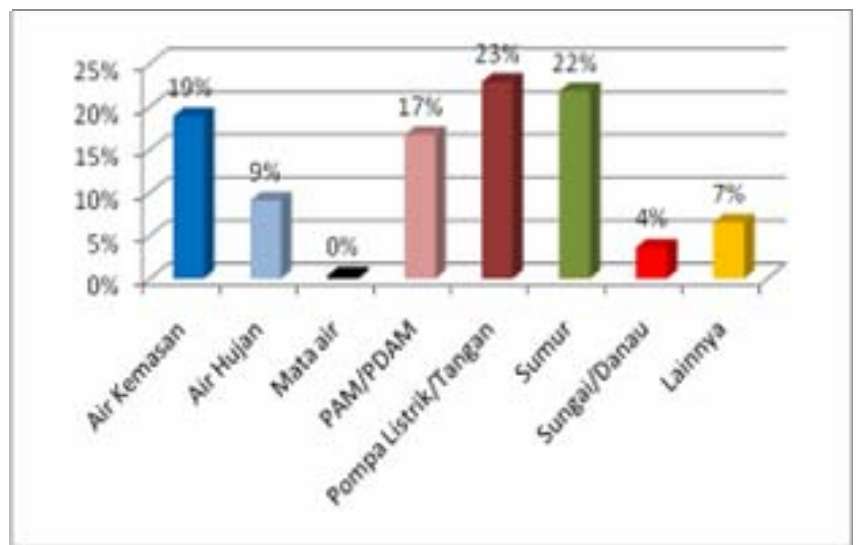

Grafik 2. Prosentase Sumber Air Bersih 2011

Dengan melakukan kategorisasi sumber air bersih, maka untuk air bersih yang terlindungi sebesar 80\%. Sebaliknya untuk sumber air bersih yang tidak terlindungi sebesar 20\%. Wilayah dengan sumber air bersih tidak terlindungi terbanyak di kecamatan Duduk Sampeyan dan Sidayu. Sementara untuk sumber air bersih terlindungi terbanyak di wilayah kecamatan Gresik, Kebonmas, Balongpanggang, Menganti, dan Bungah. Tabel 1 menunjukkan jumlah desa dengan kategori sumber air bersih di setiap kecamatan.

Beberapa penyakit yang menjangkiti manusia dibawa dan melalui media air (water borne desease) antara lain; diare, kolera, disentri, tifus, leptospirosis dan sebagainya. Penyebab berbagai penyakit 
tersebut bersumber dari bakteri patogen dan organisme seperti protozoa dan virus yang terbawa air baik air minum, air limbah rumah tangga, dan jalur-jalur lainnya (Jonshon, Michael, et.all, 2009). Penderita penyakit diare dan muntaber di kabupaten Gresik sepanjang tahun 2011 sebanyak 796 jiwa. Kecamatan Bungah menduduki tingkat tertinggi sebesar 373 jiwa, selanjutnya kecamatan Duduk Sampeyan sebanyak 276 jiwa, dan kecamatan lainnya berkisar mulai 7 hingga 55 jiwa. Wilayah yang terbebas penyakit diare dan muntaber meliputi kecamatan Gresik, Benjeng, Kedamean, Panceng, Sidayu, Ujung Pangkah dan Wringin Anom. Grafik 3 menunjukkan jumlah penderita diare dan muntaber pada wilayah kecamatan dikabupaten Gresik tahun 2011.

Tabel 1. Jumlah Desa Per Kategori Air Bersih

\begin{tabular}{|l|r|r|}
\hline \multirow{2}{*}{ Kecamatan } & \multicolumn{2}{|c|}{ Kategori Sumber Air } \\
\cline { 2 - 3 } & \multicolumn{1}{|c|}{ Terlindungi } & Tidak terlindungi \\
\hline BALONGPANGGANG & 22 & 3 \\
\hline BENJENG & 20 & 5 \\
\hline BUNGAH & 16 & 2 \\
\hline DRIYOREJO & 9 & 0 \\
\hline DUDUKSAMPEYAN & 21 & 14 \\
\hline GRESIK & 21 & 0 \\
\hline KEBOMAS & 9 & 0 \\
\hline KEDAMEAN & 14 & 6 \\
\hline MANYAR & 22 & 9 \\
\hline MENGANTI & 13 & 0 \\
\hline PANCENG & 8 & 1 \\
\hline SIDAYU & 13 & 13 \\
\hline UJUNGPANGKAH & 15 & 0 \\
\hline WRINGINANOM & $\mathbf{2 2 1}$ & 1 \\
\hline JUMLAH & & $\mathbf{5 4}$ \\
\hline \multicolumn{2}{|c|}{ SUmber: PODES 2011 (data diolah) } \\
\hline
\end{tabular}

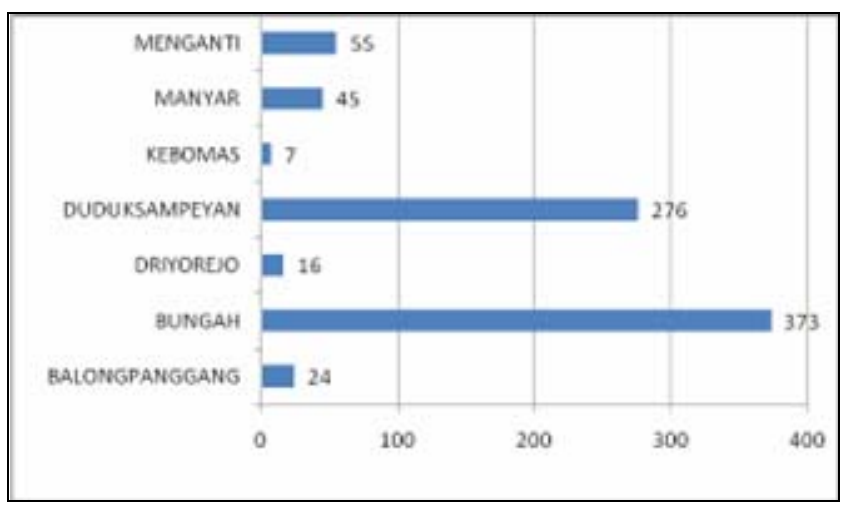

Grafik 3. Jumlah Penderita Diare/Muntaber 2011

Penyakit diare dan mutaber dapat dicegah dengan berbagai cara. Beberapa cara yang lazim digunakan adalah dengan meningkatkan dan melindungi sumber air bersih, mengolah limbah rumah tangga, dan memastikan jarak sumber air dan septik tank sesuai standar. Dengan upaya-upaya tersebut, semestinya angka penderita diare dan muntaber dapat berkurang. Fakta dilapangan bisa 
menunjukkan hal yang sama maupun berbeda/berkebalikan. Tabel 2 menunjukkan jumlah penderita diare dan mutaber pada kategori jamban keluarga.

Tabel 2. Tabulasi Silang Diare/Muntaber Per Jamban Keluarga

\begin{tabular}{|c|c|c|c|}
\hline \multirow[t]{2}{*}{ Kecamatan } & \multicolumn{3}{|c|}{ Tipe Jamban } \\
\hline & Bukan Jamban & Jamban Bersama & Jamban Sendiri \\
\hline BALONGPANGGANG & & & 24 \\
\hline BUNGAH & & 41 & 332 \\
\hline DRIYOREJO & & & 16 \\
\hline DUDUK SAMPEYAN & 39 & 34 & 203 \\
\hline KEBOMAS & & & 7 \\
\hline MANYAR & & & 45 \\
\hline MENGANTI & & & 55 \\
\hline JUMLAH & 39 & 75 & 682 \\
\hline
\end{tabular}

Berdasarkan Tabel 2 terlihat bahwa pada ketiga tipe jamban sama-sama terdapat penderita diare dan muntaber. Tipe bukan jamban menduduki jumlah penderita diare dan muntaber terkecil, dilanjutkan dengan jamban bersama dan yang terbesar adalah jamban sendiri. Kecenderungan yang ditunjukkan oleh data tersebut, semakin privat tipe jamban yang digunakan maka semakin besar jumlah penderita diare dan muntaber. Persamaan dan perbedaan karakteristik beserta kecenderungan yang ada sangat mungkin disebabkan oleh tipe jamban sendiri yang belum memenuhi standar sanitasi yang sehat dan aman. Terdapat kemungkinan jarak septik tank dengan sumber air tanah tidak memenuhi standar keamanan, pipa pembuangan air limbah yang bocor, atau air limbah rumah tangga tidak diolah dahulu sebelum dilepaskan ke lingkungan. Untuk gambaran dampak kesehatan pendayagunaan jamban secara spasial dapat dilihat pada Gambar 1.

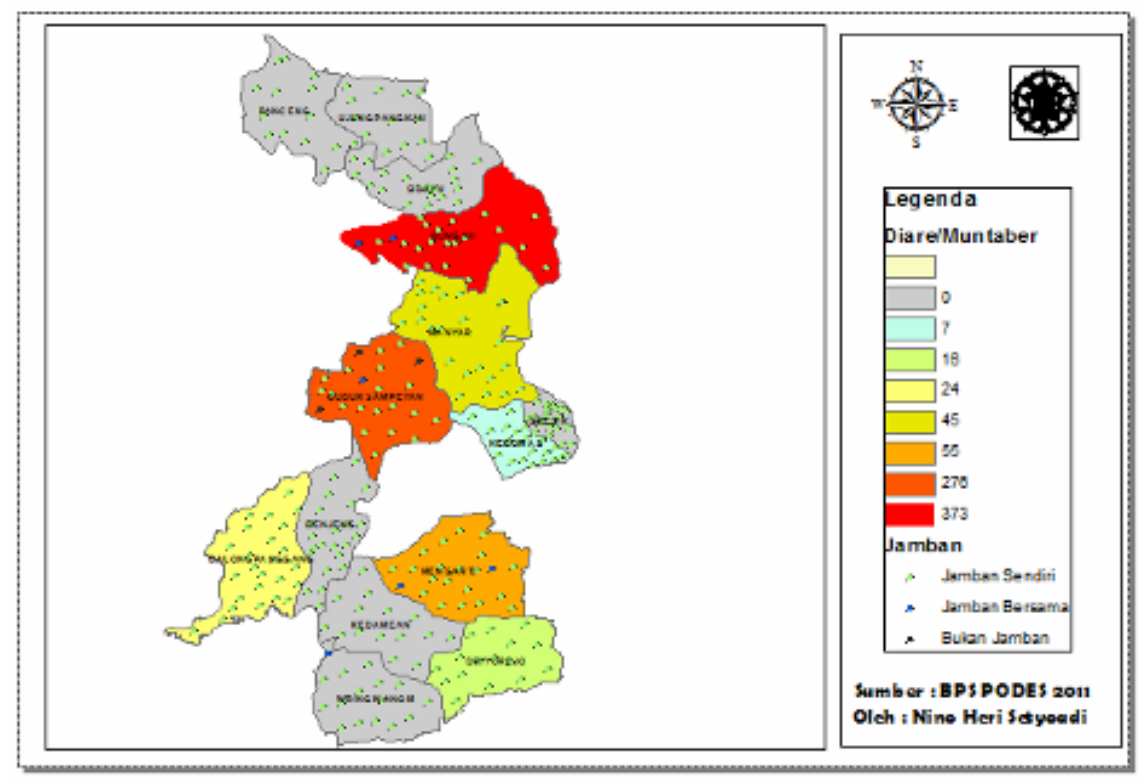

Gambar 1. Peta Distribusi Diare/Muntaber Per Jamban Keluarga 
Setelah menjelaskan pendayagunaan jamban keluarga, berikutnya penjelasan tentang pendayagunaan infrastruktur air bersih. Air bersih sangat penting artinya bagi kesehatan masyarakat. Perubahan yang dibawa oleh infrastruktur air bersih antara lain kemudahan untuk melakukan aktifitas mandi, cuci, kakus (MCK) yang sehat dan aman, kemudian memasak, minum, dan membersihkan berbagai kotoran sumber penyakit. Tabel 3 menunjukkan jumlah penderita diare dan mutaber pada kategori air bersih.

Tabel 3. Tabulasi Silang Diare/Muntaber Per Sumber Air

\begin{tabular}{|c|c|c|}
\hline \multirow[t]{2}{*}{ Kecamatan } & \multicolumn{2}{|c|}{ Kategori Sumber Air } \\
\hline & Terlindungi & Tidak terlindungi \\
\hline BALONGPANGGANG & 24 & 0 \\
\hline BUNGAH & 342 & 31 \\
\hline DRIYOREJO & 16 & 0 \\
\hline DUDUKSAMPEYAN & 30 & 246 \\
\hline KEBOMAS & 7 & 0 \\
\hline MANYAR & 35 & 10 \\
\hline MENGANTI & 55 & 0 \\
\hline JUMLAH & 509 & 287 \\
\hline
\end{tabular}

Berdasarkan Tabel 3 terlihat bahwa pada kedua kategori air bersih sama-sama terdapat penderita diare dan muntaber. Penderita diare dan muntaber pada sumber air bersih yang terlindungi lebih tinggi dari pada sumber air bersih tidak terlindungi. Kecenderungan yang nampak adalah semakin terlindungi sumber air bersih, maka semakin tinggi jumlah penderita diare dan muntaber. Tendensi ini mengundang pertanyaan, apakah sumber air bersih sudah benar-benar terlindungi dan memenuhi baku mutu air bersih yang berlaku. Jika dilihat lebih detail, proporsi jumlah penderita diare dan muntaber pada sumber air berupa sumur sejumlah 279 orang, pompa listrik/tangan 95 orang, air kemasan 72 orang dan PDAM 63 orang. Hal ini bermakna sumur dan pompa listrik/tangan yang bersumber dari air bawah tanah belum benar-benar aman. Jika dikaitkan dengan sistem sanitasi yang ada, terdapat kemungkinan adanya kontaminasi air bersih oleh air limbah rumah tangga.

Untuk air kemasan diperlukan pemeriksaan yang teliti apakah air kemasan khususnya model river osmosis, isi ulang, dan sejenisnya sudah sesuai dengan standar yang berlaku. Sementara pada air PDAM perlu dilakukan pemeriksaan lebih mendalam karena bisa jadi sumber masalahnya berada di instalasi perpipaan di masing-masing rumah tangga yang kurang aman (kebocoran, korosi kran, dan sebagainya). Untuk gambaran dampak kesehatan pendayagunaan air bersih secara spasial dapat dilihat pada Gambar 2. 


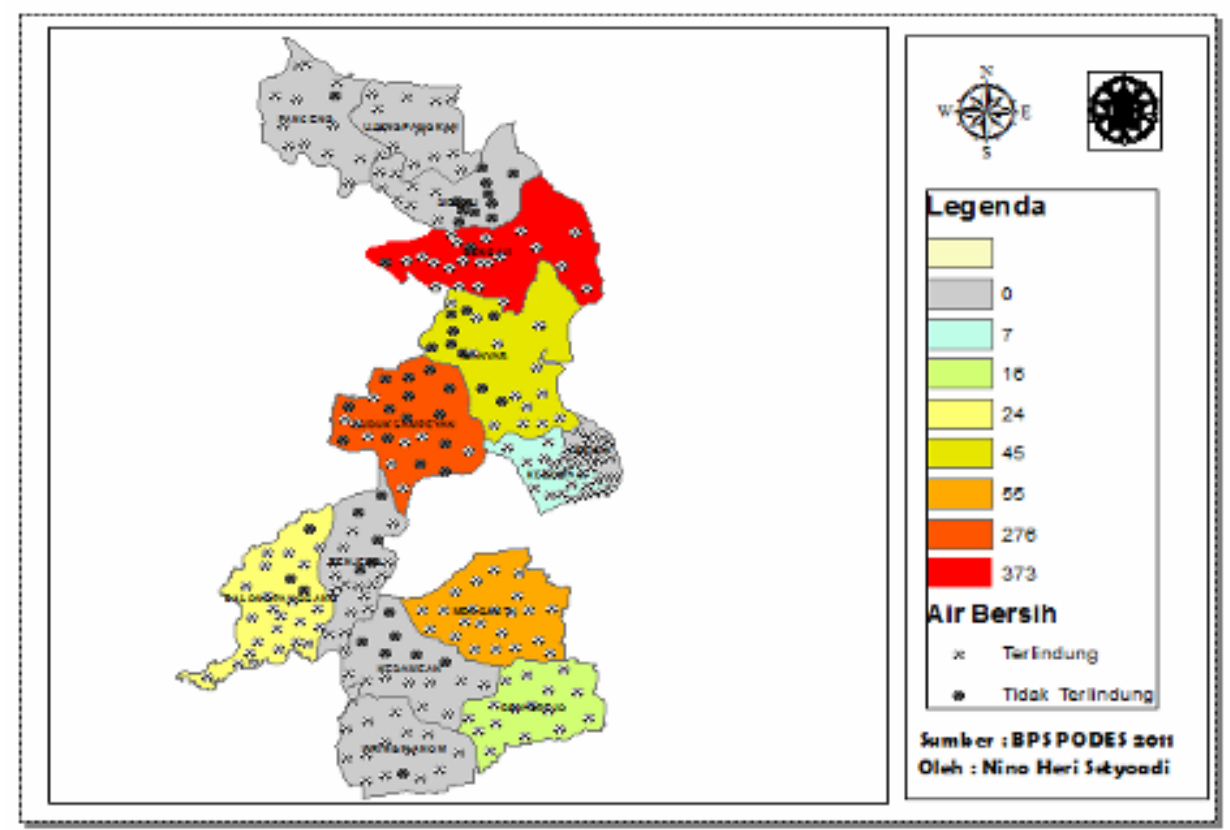

Gambar 2. Peta Distribusi Diare/Muntaber Per Sumber Air Bersih

\section{Kesimpulan dan Saran}

\section{Kesimpulan}

Berdasarkan diskusi dan pembahasan sebelumnya, maka dapat disimpulkan beberapa hal sebagai berikut:

1. Pendayagunaan infrastruktur sanitasi dan air bersih di kabupaten Gresik tahun 2011 belum mampu mendukung kesehatan masyarakat dari penyakit diare dan muntaber.

2. Lemahnya dukungan pendayagunaan infrastruktur sanitasi bisa disebabkan oleh jarak septik tank dengan sumber air tanah tidak memenuhi standar keamanan, pipa pembuangan air limbah yang bocor, atau air limbah rumah tangga tidak diolah dahulu sebelum dilepaskan ke lingkungan.

3. Lemahnya dukungan pendayagunaan infrastruktur air bersih bisa disebabkan oleh sumber dari air bawah tanah belum benar-benar aman dan terdapat kemungkinan adanya kontaminasi air bersih oleh air limbah rumah tangga.

\section{Saran}

Untuk menghadapi dampak pendayagunaan infrastruktur sanitasi dan air bersih terhadap kesehatan masyarakat, maka dapat dilakukan beberapa strategi adaptasi berikut ini:

1. Meningkatkan cakupan air bersih perpipaan (PDAM atau HIPPAM) yang mutu kualitas airnya telah sesuai standar. 
2. Mempromosikan sistem sanitasi perkotaan untuk wilayah perkotaan dan sistem sanitasi komunal yang aman dan ramah lingkungan.

3. Melakukan sosialisasi berkala tentang standar pengelolaan limbah skala rumah tangga dan teknologi tepat guna (TTG) pengelolaan air bersih.

4. Mengembangkan model reward and punishment dalam pengendalian permukiman khususnya dalam bidang sanitasi dan air bersih.

5. Melembagakan ketentuan-ketentuan pengelolaan sanitasi dan air bersih yang sehat, aman, dan ramah lingkungan dalam peraturan daerah.

\section{Daftar Pustaka}

BPS. (2011). PODES 2011: Pedoman Pencacah, Jakarta: Badan Pusat Statistik Pusat.

de Moel, PJ. (2006). Dringking Water: Principles and Practices, Singapore: World Scientific Publishing, co.ltd.

Dinkes Kab. Gresik. (2007). Profil Kesehatan Kabupaten Gresik Tahun 2006, Gresik: Dinas Kesehatan Kab. Gresik.

Jonshon, Michael, et.all. (2009). Tworts Water Supply $6 \quad$ Edition, Oxford: Published by Elsevier Ltd. All rights reserved.

Kemenkes. (2011). Situasi Diare di Indonesia, Bulletin Jendela: Data dan Informasi Kesehatan Triwulan II, 2011 hal 1, 9-10.

Rizki, Bhimo dan Saleh, Samsubar. (2007). Keterkaitan Akses Sanitasi dan Tingkat Kemiskinan: Studi Kasus di Propinsi Jawa Tengah, Jurnal Ekonomi Pembangunan, Vol. 12 No.3, Desember 2007, hal. 223-233.

Salendu, Belinda. (2010). Quality Assessment and Interrelation of Water Supply and Sanitation: A Case Studi of Yogyakarta City, Indonesia, Unpublished Thesis, Enschede: ITC-Netherlands.

Usman, S. (2010). Infrastruktur dan Pembangunan Masyarakat, Yogyakarta: PIPM Sekolah Pasca Sarjana Universitas Gadjah Mada (materi perkuliahan).

WHO. (2007). Economic and Health Effects of Increasing Coverage of Low Cost Household Drinking-Water Supply and Sanitation Interventions to Countries Off-Track to Meet MDG Target 10, Geneva: WHO Press.

WHO. (2011). Guidlines for Dringking Water Quality - 4 Edition, Geneva: WHO Press. 